\title{
The Effects of Story-Telling on the Language Skills of Pupils at the Early Childhood Education Stage of the Central Region of Ghana
}

\author{
Naa Korkor Larbi-Appiah Joshua Baatimah Beatrice Antwiwaa Ali Yaaku Sumani Mohammed
}

\begin{abstract}
This purpose of the study was to examine the effects of story-telling on the language skills of pupils in early childhood education at the Elmina Catholic Boys Primary School in the Central Region of Ghana. The study employed the action research design. Using the census sampling procedure, 34 respondents comprising 32 primary two (2) pupils and two (2) class teachers were selected for the study. Data gathered from the use of the interview guide and tests were analysed using frequencies, percentages and paired-sample t-test. Among the prominent causes of poor language skills among pupils were the fact that, friends laughed at pupils if they talk and made mistakes (peer pressure) and difficulty pupils had in expressing themselves (personality differences). Also, the post-test scores of the language skills of the pupils were higher than that of the pre-test scores. This means that, the intervention (storytelling) had a positive effect/impact and improved the language skills of the pupils.
\end{abstract}

Keywords: Story-telling, Language Skills

DOI: $10.7176 / \mathrm{JEP} / 11-24-15$

Publication date:August $31^{\text {st }} 2020$

\section{INTRODUCTION}

The early years of a child's development are very important not only because they lay the basis for human development but also because experiences children are exposed to during that period have lasting influence in childhood. Early Childhood Education is a term that refers to educational programs and strategies geared towards children from birth to the age of eight (UNESCO, 2010). It is the process or approach deliberately intended to effect developmental changes (physical, cognitive, social and emotional) for those below the age of 8 years and the foundation stage referred to earlier (Ampadu \& Ofosu, 2007).

Early Childhood development is a foundation on which our education for all and especially basic education should be founded (Mwai, 2003). Chomsky (1966) also adds that at every stage of the child's development, there is the need to build on their previous competency level of the language skills. This, therefore, means that the critical thinking abilities of children are to be advanced at every stage of the child's development. One of the ways of ensuring that is by the use of storytelling.

Storytelling can be described as a process of connecting a chain of events and present them in the form of a story (Jupit, 2012). Storytelling as a pedagogical strategy is not new or unique. It is one of the most attainable teaching tools available for all instructors, precisely language instructors. It is broadly used in language instruction. It is a special activity that may be reserved for special times or all times. It can be utilized in all learning levels and ages for various objectives (Atta-Alla, 2012). Karlsson (2012) also believes that storytelling is characterized as powerful, motivating and efficient. He explains that, actual and fictitious information is quickly learnt, retained, instantly recalled and accurately applied when delivered in the form of a well-told story.

Macbeath (2010) notes that the English is the official language of Ghana and English language in Ghana has since 1957 been the medium of instruction in schools (from primary four), subsequent to the declaration of the language policy for schools in the same year. This is meant to meet the country's inter-ethnic communication and in the various dialogues that relate to democratic practice and governance. For this reason, the development of language skills in students could be one stepping stone towards achieving this. However, studies and research by organisations such as the Curriculum Research Development Division (2010) and individuals such as David Nunan (1997), Kortner and Hong (1995) as well as personal observations revealed that the language skills, specifically listening and speaking, have been overlooked in most instructional sessions in schools. Public opinion, as confirmed by Kortner and Hong (1995) also holds that attention seems to have been paid to content aspects of various subject areas rather than the language competencies and the enhancement of skills that come with the language. Language skills is very important when it comes to educating children. It really indicates whether children are progressing academically, socially and emotionally. In most settings, children are only able to speak in their local dialect but not in the second language. This really makes it difficult for them to cope with learning especially in the classroom and sometimes among their peers. From personal experiences as teachers of primary two pupils, it was realised that, the students exhibit some challenges in communicating. Though pupils are often engaged in reading comprehension and other interactive activities, they can hardly express themselves in simple English terms. However, they are able to do so in their local dialect. It is on this background that the researchers decided to undertake this study in order to assess the effects of story-telling on the language skills of pupils in 
early childhood education at the Elmina Catholic Boys Primary School. The research attempts to find solutions to following research questions: "What are the causes of poor language skills among pupils?"; What roles do teachers play in improving the language skills among pupils as well as "What is the impact of storytelling on the language skills of pupils?" The study involved pupils from the Elmina Catholic Boys Primary School in carrying out the study. The study helps teachers to come to the realization that, storytelling can be used to improve the language skills of pupils. Teachers can therefore adopt storytelling as one of their classroom teaching strategies to improve the language skills of their pupils. The study also enables pupils to overcome their language difficulties in order to communicate better among themselves. Again, it is expected that, the study would add up to the information already gathered on the subject by previous studies. The subsequent paragraphs consider the Methodology, Results and Discussions, Conclusions and Recommendations.

\section{METHODOLOGY}

\section{Research Design}

The design used for the study was the action research design. Action research was adopted for the study. Action research design aims at identifying a problem in a particular setting, providing interventions to the problem and reporting on the impacts of the intervention (Reason \& Bradbury, 2001). Action research design was chosen for this study purposely to ascertain how storytelling can be used to improve the Language Skills of pupils in the classroom. But the design has its own pitfalls as it it often takes place on the local scale and it cannot be extended to a broader context.

\section{Population}

A population in a research refers to the lager group of people with common observable features to which one hopes to apply the research result (Fraenkel \& Wallen, 2003). It must be noted that whatever the basic unit, the population always comprises the entire aggregation of elements in which the researcher is interested. The population for the study consists of all the primary two pupils of the Elmina Catholic Boys Primary School class and their class teacher. There were 32 pupils together with their two (2) class teachers totaling 34 respondents.

\section{Sample and Sampling Procedure}

A sample size is basically the subset of actual number of individuals of the population. A sample size helps considerably to define the accuracy of the research results. It has been assumed by scholars that the larger the sample size, the more the accuracy or precision of the results of the study, conversely sample size tends to decrease with relatively large population (Welman, Kruger \& Mitchell, 2005). The sample for the study consists of two (2) teachers and all the 32 pupils of the primary two (2) class totaling 34 respondents. Census sampling technique was used to select all the 34 respondents for the study. The census sampling technique was employed due to the limited number of respondents in the study, and also on the bases that, majority of the pupils if not all have challenges with Language Skills. Also, children at that level may exhibit emotional instability if some of them are not selected for the study.

\section{Research Instruments}

The interview guide (for pupils and class teachers) and a test were the instruments for data collection. The interview guide was administered to both pupils and teachers. Reasons for the choice of the interview guide were that, the interview guide is more flexible and appropriate when the number of respondents is few. The interview guide for the pupils had two sections (Sections A\&B). Section A considered the background characteristics of the pupils and section $\mathrm{B}$ was on the causes of poor language skills among pupils (research question 1). The interview guide for the teachers had three sections (Section A, B \& C). Section A considered the background characteristics of the teacher whereas sections $\mathrm{B}$ and $\mathrm{C}$ looked at the causes of poor language skills among pupils (research question 1) as well as the roles teachers play to improve the language skills of pupils (research question 2).

A test item based on pictures and story-telling were given to the pupils. The test items were marked over $100 \%$ and this catered for the research question 3 (the impact of storytelling on the language skills of pupils). Data collection for research question 3 went through three stages namely; pre-intervention, intervention and post intervention.

\section{Pre-Intervention}

The primary purpose of this intervention was to measure the language skills (speaking ability) of the pupils before and after the intervention. The participants were asked to describe an object, narrate a given picture, and compare and two things. In order to examine inter-rater reliability, the researchers worked with another teacher from a different class. The responses were scored independently by the researchers and the colleague rater. The participants were scored on their use of correct grammar, vocabulary, pronunciation and their ability to be fluent. Overall, the item was scored over 100\%. The pre-intervention took 10-15 minutes for each participant to complete.

\section{Intervention}

The purpose of the intervention was to determine whether storytelling could help improve language skills (speaking ability) of pupils. In this study, an English story was acquired by the researchers with their visual pictures. The researchers presented one story and participants had to listen to the story, each of them had to make the oral 
summary of the story and answer questions on the story as well thus, the listening and speaking stage. The intervention process was as follows:

1. Teaching the new words and phrases before telling the story.

2. Checking the participants' comprehension of the new words.

3. Asking them to guess the story.

4. Telling the story by showing pictures alongside.

5. Asking them to listen to the story once more and prepare to summarize and answer questions in the next session.

The following questions were asked about the stories:

1. Who were the main characters of the story? Mention their names one by one.

2. Was there a problem in the story? What was it?

3. What happened first, next, and last?

\section{Post-Intervention}

In order to determine whether using retelling stories has any effect on the subjects' speaking ability (language skills), after obtaining the scores of the pre-intervention and intervention, the items were marked over $100 \%$ and frequencies and percentages of the scores was calculated. Then, in order to find out whether the differences between the groups were statistically significant, paired sampled t-test was used for the analysis of the research question 3

Data Analysis

This study sought to determine the effects of the use story-telling on the language skills of pupils in Elmina Catholic Boys Primary School. The study adopted the use of frequencies and percentages for analyzing research questions 1 and 2 . Research question 3 was analysed using the paired samples t-test. These were done using the Statistical Product and Service Solutions.

\section{RESULTS AND DISCUSSION}

Data was analyzed and presented systematically beginning with the background information of the respondents, followed with the research questions that guided the study. Table 1 shows the characteristics of primary two (2) pupils and the class teachers of the Elmina Catholic Boys Primary School who served as respondents for the study. Table 1: Characteristics of Sampled Pupils $(\mathbf{n}=\mathbf{3 2})$

\begin{tabular}{|l|l|l|l|}
\hline Variable & Subscale & No. & $\%$ \\
\hline Gender & Male & 32 & 100.0 \\
\hline Age & 7 years & 26 & 81.25 \\
\hline & 8 years & 6 & 18.75 \\
\hline
\end{tabular}

Source: Field data, 2020

From Table 1, it can clearly be read that all the pupils were males. This represented $100.0 \%$. With respect to age, 26 pupils which represent $81.25 \%$ were 7 years and 6 pupils representing $18.75 \%$ were 8 years. Thus the majority of the pupils were 7 years old. This is not surprising because, age 7 is the appropriate age for primary two (2) pupils. The background characteristics of the teachers are presented below.

\section{Background Characteristics of the Class Teachers}

In terms of gender, one of the primary two (2) pupils was a male whereas the other was a female. Both teachers were between 31-40 years. In line with their highest level of educational qualification, one had a first degree and the other had diploma in education. This means that, both teachers were professionally trained teachers. Therefore, the researchers anticipate that, the teachers will be able to provide the necessary information needed for the study concerning the roles they played in helping pupils improve on their language skills. Also, one of the teachers had taught for 7 years and the other had taught for 13 years. This means that both teachers had teaching experience for a number of years.

This section presents the results and discussions of data collected to answer the three research questions formulated to guide the study. It comprised data from the interview guide and the test.

\section{Causes of Poor Language Skills among Pupils}

Research Question 1: What are the causes of poor language skills among pupils? The main objective of this research question was to find out the causes of poor language skills among primary two (2) pupils of the Elmina Catholic Boys Primary School. The responses are illustrated in Table 2. 
Table 2: Causes of Poor Language Skills $(n=32)$

\begin{tabular}{|l|l|l|}
\hline Statement & $\begin{array}{l}\text { Yes } \\
\mathrm{N}(\%)\end{array}$ & $\begin{array}{l}\text { No } \\
\mathrm{N}(\%)\end{array}$ \\
\hline Boring classroom lessons. & $24(75.0)$ & $8(25.0)$ \\
\hline Unwillingness to talk or engage in an activity (Personality Differences). & $32(100.0)$ & $0(0.0)$ \\
\hline My friends will laugh at me if I talk and make a mistake (Peer Pressure). & $32(100.0)$ & $0(0.0)$ \\
\hline $\begin{array}{l}\text { Failure to use variety of materials and methods (Leading to lack of } \\
\text { understanding of lessons). }\end{array}$ & $16(50.0)$ & $16(50.0)$ \\
\hline I do not like reading (Poor reading habits of pupils). & $28(87.5)$ & $4(12.5)$ \\
\hline I have difficulty in expressing myself (Emotional problem). & $32(100.0)$ & $0(0.0)$ \\
\hline
\end{tabular}

\section{Source: Field data, 2020}

Table 2 presents the views of pupils on the causes of poor language skills among them. It is evident from Table 2 that, the majority of the pupils unanimously agreed that, they are unable to communicate because, their friends will laugh at them if they talk and make mistakes; they were unwilling to talk or engage in an activity (personality differences); and they had difficulty in expressing themselves (emotional problem). Each of these items recorded $100.0 \%$. Also, 28 pupils representing $87.5 \%$ responded 'yes' to the statement; "I do not like reading (poor reading habits of pupils). Thus, the majority of the pupils did not like reading or had poor reading habits. Again, the majority of the pupils did not like reading because classroom lessons were boring. With this item, 24 pupils representing $75.0 \%$ agreed, and 8 pupils representing $25.0 \%$ disagreed. In line with this finding, Lunenburg (2010) asserts that, negative attitude of towards reading, people's backgrounds, perceptions, values, biases, needs, and expectations cause poor language skills among students. However, pupils were uncertain as to whether teachers' failure to use variety of materials and methods leading to lack of understanding of lessons was a cause of their poor language skills. Here, 16 pupils representing 50.0\% responded 'yes' and 16 pupils representing 50.0\% responded 'no'.

From the foregoing, it can be concluded that, pupils' inability to communicate were as a result of many factors. Prominent among them were the fact that, friends laughed at pupils if they talk and made mistakes (peer pressure); unwillingness to talk or engage in an activity (personality differences); as well as difficulty pupils had in expressing themselves. Also, pupils did not like reading or had poor reading habits and classroom lessons were boring and that affected their communicative skills. However, pupils were uncertain as to whether teachers' failure to use variety of materials and methods leading to lack of understanding of lessons was a cause of their poor Language Skills.

\section{Roles Teachers Play in Improving the Language Skills of Pupils}

Research Question 2: What roles do teachers play in improving the language skills of pupils?

This section reports teachers' answers to the question, "What roles do teachers play in improving the language skills of primary two (2) pupils in Elmina Catholic Boys Primary School?" Teachers are considered the "Drivers" in the classroom learning. They steer the atmosphere in the classroom to ensure that teaching and learning runs smoothly. Thus, to achieve the learning goals and objectives of the school. From the findings, it is very clear the teachers admitted that they had a role to play in helping pupils improve on their language skills. In relation to this, both teachers responded 'yes' to the statement; "Do you encourage all students to participate in class discussion". In doing this, the teachers indicated that, they help pupils to improve upon their vocabulary and corrected errors made by pupils. Also, both teachers indicated that, they encourage group discussion/work. With this, one of the teachers said that, putting pupils in groups helps them to be bold and express themselves among their peers. The other teacher also responded that:

"It enables children in the group to share ideas together and socialise" (Teacher 1)

Again, both teachers responded 'yes' to the question; "Do you engage pupils in dramatization/role play?' In line with this, the teachers indicated that:

"It helps them to recall vividly what they have learnt" (Teacher 1)

"It helps pupils to remember whatever they have learnt" (Teacher 2)

Also, both teachers agreed that, the have got an English/Reading corner in the classroom and make time for pupils to visit the corner frequently. One of the teachers indicated that, this helps them to learn on their own for more understanding of the lesson. The other teacher also said that:

"It helps them with their identification and pronunciations of letter and words" (Teacher

However, both teachers indicated that, they do not use open-ended questions in class. They gave the following as their reasons:

"At their level, children will find it difficult to answer open-ended questions well" (Teacher 1)

"The teacher will not get the answer to the question correctly" (Teacher 2).

As to whether teachers show films or encourage pupils to watch films that model conversation skills, both teachers agreed to the statement. The teachers explained that, this helps pupils to improve upon their language skills. Once more, both teachers responded 'yes' to the question; "Do you encourage reading and re-telling stories?" 
The teachers indicated that:

"It helps pupils to improve their conversational skills and recall what they have learnt"

"It helps pupils to acquire reading skills and vocabulary" (Teacher 2).

From the above discussions, it can be concluded that, the teachers performed various roles in helping pupils to improve upon their language skills. Some of these roles included: encouraging all pupils to participate in class discussions; encouraging group work/discussion; engaging pupils in dramatization/role play; showing or encouraging pupils to watch films that model conversation skills; as well as encouraging reading and re-telling of stories. Also, teachers indicated that, they had an English/reading corner in the classroom and made time for pupils to visit the corner frequently. However, both teachers indicated that, they do not use open-ended questions in class because, at their level, the children will find it difficult to answer and the teacher will not get the correct answers to the questions.

\section{Impact of Story-telling on the Language Skills of Pupils}

Research Question 3: What is the impact of story-telling on the language skills of pupils? This research question sought to find out whether use of storytelling has any impact on the language skills of primary two (2) pupils. The paired sample t-test was used in the analysis in order to ascertain whether there was a significant difference between the post-test and the pre-test scores of the pupils regarding the use of the storytelling. Findings from the study are presented in Table 3 .

Table 3: Paired Sample T-test on the Impact of Storytelling on Pupils' Language Skills

$\begin{array}{lllll}\text { Group N } & \text { Mean Std. Dev. } & \text { Df } & \text { t- }\end{array}$

value

\begin{tabular}{|c|c|c|c|c|c|c|c|}
\hline \multirow[t]{2}{*}{ Storytelling } & Pre-test & 32 & 35.65 & 3.92 & & & \\
\hline & Post-test & 32 & 71.30 & 405 & & 2.39 & 0.017 \\
\hline
\end{tabular}

Table 3 shows the results of the paired sample t-test on pre-test and post-test scores of the pupils' language skills regarding the use of storytelling. From Table 3, it was realized that the pre-test score had a mean score of $(M=35.65 ; S D=3.92)$ while the post-test score had a mean score of $(M=71.30 ; S D=4.05)$. This shows that the post-test scores of the language skills of the pupils were higher than that of the pre-test scores. This means that, the intervention (storytelling) had a positive effect and improved the language skills of the pupils. Again, the standard deviation $(S D=4.05)$ of the post test score indicates that the individual test scores of the language skills of the pupils varied more than that of the pre-test scores $(S D=3.92)$. However, when the mean scores of the two groups were tested using the paired samples t-test at $5 \%$ significant level, two-tailed, the results revealed that there was a statistically significant difference between the pre-test scores of pupils and the post test scores of pupils' language skills $(t(31)=2.39, p=0.017)$. Therefore, the use of storytelling is significant and has a positive effect/impact on the language skills of the pupils.

The finding is in agreement with studies which suggest that there are positive effects in intellectual, social and emotional development of students who are encouraged to use storytelling. As students engage in storytelling they learn to listen, to participate in and understand narrative discourse and create a path to more sophisticated use of language, reading and writing in their everyday lives (Mallan, 1992). This is confirmed by Brice, (2004) who said that storytelling/retelling of stories is a successful strategy to increase pragmatic oral skills, the ability to use language in specific contexts for specific purpose, leading to greater ability to write. Storytelling is an effective tool in improving the oral competencies of students (Isbell, Sobol, Lindauer \& Lowrance, 2004). Becoming verbally proficient can contribute to a student's ability to communicate effectively and successfully. Negotiation, discussion, and tact are peacemaking skills. Being able to accurately express one's thoughts and feelings is important in everyday communication.

Both telling a story and listening to a well-told tale encourages students to use their imaginations. As Mallan, (1992) stated storytelling helps develop the imagination which in turn builds on problem-solving competencies. Therefore, developing the imagination can empower students to consider new and inventive ideas. In other words developing the imagination can contribute to self-confidence and personal motivation as students envision themselves competent and able to accomplish their hopes and dreams.

\section{Conclusions}

These conclusions were drawn as a result of the findings realized for the study. Pupils' inability to communicate was as a result of many factors. Prominent among them were the fact that, friends laughed at pupils if they talk and made mistakes (peer pressure); unwillingness to talk or engage in an activity (personality differences); as well as difficulty pupils had in expressing themselves. Also, pupils did not like reading or had poor reading habits and classroom lessons were boring and that affected their language skills. Again, the teachers performed various roles in helping pupils to improve upon their language skills. Some of these roles included: encouraging all pupils to participate in class discussions; encouraging group work/discussion; and engaging pupils in dramatization/role 
play. However, the teachers did not use open-ended questions in class because, at their level, the children will find it difficult to answer. Finally, the intervention (storytelling) had a positive effect/impact and improved the language skills of the pupils, and the results revealed that there was a statistically significant difference between the pre-test scores of pupils and the post test scores of pupils' language skills.

\section{Study Recommendations}

The following recommendations were made for policy makers:

1. Teachers should adopt diverse ways of delivering lessons so that lessons will not be boring to pupils. Again, teachers need to put stringent measures in place to curtail those pupils who make fun of their friends when they make mistakes and encourage pupils to adopt positive attitudes towards reading.

2. It is recommended that, instead of recall of factual information, teachers should adopt questioning techniques that require learners to give explanations and teachers should focus on the logical and sequential flow of ideas and presentation of issues instead of just giving correct answers. This will help learners improve upon their language skills.

3. Teachers should adopt storytelling as an intervention to the poor communication among pupils since it has a positive impact and improves pupils' language skills.

\section{REFERENCES}

Abdel-Hack, E.M., \& Helwa, H.S.A.A. (2014). Using digital storytelling and weblogs instruction to enhance EFL narrative writing and critical thinking skills among EFL majors of faculty of education. Educational Research, $5(1), 8-41$.

Abdolmanafi, R. S. J., \& Qarajeh, M. (2014). Digital storytelling in EFL classrooms: The effect on the oral performance. International Journal of Language and Linguistics, 2 (4), 252- 257.

Adams, E.W. (2013). Resolutions to some problems in interactive storytelling. England: University of Teesside.

Ahmed, C. M., Yossatorn, Y., \& Yossiri, V. (2012). Students' attitudes towards teachers using activities in EFL class. International Journal of Academic Research in Business and Social Sciences, 2(5), 158-164.

Akinbobola, A. O. (2009). Enhancing students' attitude towards Nigerian senior secondary school physics through the use of cooperative, competitive and individualistic learning strategies. Australian Journal of Teacher Education, 34 (1), 12.

Alemi, M., Tajeddin, Z., \& Mesbah, Z. (2012). Willingness to communicate among EFL Learners. Germany: LAP LAMBERT Academic Publishing.

Al-Mansour, N. S., \& Al-Shorman, R. A. (2011). The effect of teacher's storytelling aloud on the reading comprehension of Saudi elementary stage students. Languages and Translation, 23, 69-76.

Andrews, D. H., Hull, T. D., \& DeMeester, K. (Eds.). (2010). Storytelling as instructional method. The Netherlands: Sense Publishers.

Andrews, D. H., Hull, T. D., \& Donahue, J. A. (2009). Storytelling as an instructional method, definitios and research questions. Interdisciplinary Journal of Problem-Based Learing, 3 (2), 6-7.

Association of American Colleges and Universities. (2015). Written communication value rubric. Retrieved from https://www.aacu.org/value/rubrics/written-communication.

Atta-Alla, M. N. (2012). Integrating language skills through storytelling. English Language Teaching, 5(12), 1-2.

Azizah, C. N., Abdul M. A., Aziz, N., \& Abu, B. R. M. (2011). Multiple intelligence ensures usability of digitalstorytelling for preschool children. Proceeding of the International Conference on Advanced Science Engineering and Information Technology, 117-123.

Babacock, J., \& Parker, R. (2014). Effective communication through visual storytelling. Jabian Journal, 54-59.

Baker, G. S. (2011). Fitly spoken. USA: Brighton Publishing LLC.

Beebe, S. A., Beebe, S. J., \& Redmond, M. V. (2010). Interpersonal communication foundations: Introduction to interpersonal communication. In Interpersonal communication: Relating to others. USA: Pearson Education.

Bognar, L. (2009). Storytelling and puppetry in higher education. Osijek, Croatia: Teacher Training Faculty.

Bozen, A. (2011). 100 great EFL quizzes puzzles and challenges. USA: Crazy Chopstick Publications.

Bradford, D. (2011). Language Skills as the SACS-QEP. Australia: Communications Department, Melbourne Campus.

Cody, K., \&Wagner, T. (2012). Does oral storytelling help first graders become better writers? Journal of Teacher Initiated Research, 5, 1-12.

Deakin University (2016). Graduate learning outcomes Melbourne, Australia: Deakin University.

Kumar, M. S. (2015). Activating the communication: The role of computers, e-books and internet in the context of second language acquisition. USA: International E-Publication. International Science Congress Association.

Martínez, B. I. (2007). A story-based approach to teaching English: A classroom experience. Encuentro, 17, 5256.

McLellan, H. (2006). Digital storytelling in higher education. Journal of Computing in Higher Education, 19 (1), 
65-79.

McPheat, S. (2010). Effective Language Skills. United Kingdom: MTD Training \& Ventus Publishing.

Rajadurai, S. (2015). Effective Language Skills in English for tourism professionals. International E-Publication. USA: International Science Congress Association.

Wallin, J. (2015). Storytelling and language development. Sweden: Malmöhögskola/Lärandeoch samhälle.

Youssef, A. I. M. (2005). Language Skills. Cairo: Center for Advancement of Postgraduate Studies and Research in Engineering Sciences, Faculty of Engineering Cairo University (CAPSCU). 